\title{
SOME REFLECTIONS ON INCOME AVERAGING AND A PROPOSAL
}

\author{
RoBert C. TAYLOR*
}

$\mathrm{H}^{\mathrm{EW}}$ people realize that the federal income tax system in its present form discriminates against individual taxpayers with irregular incomes. This discrimination is the unfortunate result of a conflict between progressive income tax rates and the annual accounting period. Under the present rate structure, federal income taxes take a progressively larger share of the taxpayer's dollar as he moves up the graduated scale. At the same time, the taxpayer is compelled to pay the tax at the end of each taxable year regardless of the amount of income he receives in other years. No useful purpose would be served by discussing the theory behind each of these two cornerstones of the individual income tax. Both are firmly imbedded in the foundation of the tax structure and are not likely to be replaced. However, it is clear that the combination of progressive income tax rates and the annual accounting period causes inequities between the taxpayers who receive their yearly incomes in stable amounts over a period of years and taxpayers whose incomes vary over the same period.

For example, assume that $A$ and $B$ are unmarried taxpayers who are not heads of households. They both receive the same total amount of taxable income over a period of four years. $A$, an employee of a corporation, receives one raise in salary during this period. $B$, a farmer, has two poor years because of bad weather conditions and then two good ones. The tax liability of each (at constant 1955 rates) will be as follows:

\begin{tabular}{ccccc} 
& Taxpayer $A$ & \multicolumn{4}{c}{ Taxpayer $B$} \\
Year & Taxable Income & Tax & Taxable Income & Tax \\
1955 & $\$ 8,000$ & $\$ 1,960$ & $\$ 2,000$ & $\$ 400$ \\
1956 & 8,000 & 1,960 & $4,000$. & 840 \\
\hline
\end{tabular}

* A.B. 1949, LL.B. 1952, Duke University; LL.M. 1956, S.J.D. 1958, Georgetown Law Center. Associated with Golden, Croley, Howell, Johnson, \& Mizell, Attorneys, Dallas, Texas; member of the North Carolina and District of Columbia bars. Formerly Attorney, United States Tax Court. 
$1957 \quad 9,000$

$$
2,300
$$

I0,000

2,640

1958

9,000
9,000
$\$ 34,000$

$\frac{2,300}{\$ 8,520}$

$\frac{18,000}{\$ 34,000}$

$\frac{6,200}{\$ 10,080}$

Farmers are not the only victims of this effect. Doctors and dentists undergo long periods of education and training at little or no pay before entering practice and the higher income brackets. The income of lawyers frequently follows a similar pattern. Taxpayers in the entertainment field and professional athletes receive incomes which fluctuate yearly with the caliber of the taxpayer's performance. The small businessman may prosper or barely subsist from year to year, depending upon business conditions generally, consumer demand for his goods, and other factors. In sum, a variety of taxpayers are likely to receive income in widely varying amounts from year to year. If they do, they will pay more income tax over a period of years than they would have paid if they had received the same total amount more evenly over the same period.

\section{I}

Why Is a Generat Income-Averaging Provision Necessary?

Because taxpayers receiving income in unequal amounts over a period of years bear an unfair tax burden, it has been frequently suggested in the past that such taxpayers be permitted under the Internal Revenue Code to "average" income over a period of years. ${ }^{1}$ Income averaging is not a well known concept, but at the same time, it is not particularly difficult to understand. "Income averaging" means that no matter how much income is received in any one of several taxable years, the total amount of income received during a period of years is treated for tax purposes as if that income had been received in equal amounts over the same period. In other words, if a taxpayer is permitted to average income for a period of, say, three years, then his income in each of those three years will be the same. Obviously, a provision which would permit taxpayers to distribute irregularly received income evenly over a period of years would eliminate the discrimination now caused by the conflict between the progressive tax rates and the annual accounting period. Some sort of general income-averaging scheme, therefore,

${ }^{1}$ See generally, Steger, Averaging Income for Tax Purposes: A Statistical Study, 9 NAT'L TAX J. 97 (1956); Driscoll, Income Averaging for Individual Income Tax Purposes, in Federal Tax Policy for Economic Growth and Stability, S. REP. No. 1310 , 84th Cong., 2d Sess. 175 (1956). 
seems admirably suited to accomplish this purpose. But, as is so often the case, proposals sound in principle are frequently not so sound in operation. Income-averaging schemes offered in prior years, with one exception, have been spectacularly unsuccessful.

\section{II}

\section{Prior Experience with General Income-Averaging Devices}

Dozens of income-averaging plans have been proposed in the pastbeginning as long ago as $1799 .{ }^{2}$ Space does not permit a detailed examination of all of these proposals. However, the general characteristics of most of them may be noted.

(1) Simple averaging. Under a simple averaging plan, the taxpayer merely takes a group of taxable years and computes his tax on the basis of an average yearly income over the entire period. No mathematical problems are involved here, because the taxpayer merely adds up the amounts of income received over the period and divides by the number of years in the period. His tax liability will be the same in each year of the averaging period, even though he received widely varying amounts of income in each year of the averaging period.

(2) Moving average. Moving average devices work in a similar manner, except that the taxpayer uses the taxable year and certain number of preceding years as the averaging period. For example, if taxpayer $A$ were permitted to use a three-year moving average, he would add his current taxable year income to the income of the two preceding years and divide by three. The figure arrived at in this manner would be the average taxable income for the period.

(3) Averaging based on source of income. Some proposals have attempted to permit averaging only as to certain types of income. ${ }^{3}$ Generally, this method involves permitting the taxpayer to treat the particular item of income as if he had received it in equal amounts over a prior period of years. Because receipt of a particular type of income is a prerequisite to the use of an averaging technique of this kind, such proposals are not true general income-averaging devices.

\footnotetext{
${ }^{2}$ For an excellent summary of the historical development of income averaging, see Driscoll, supra note $I$. Great Britain enacted the first averaging plan with the earliest British income tax act in $\mathbf{1} 799$.

${ }^{3}$ E.g., one author has offered a proposal that would permit a spreadback for five years of income such as accumulated dividends on preferred stock and accumulated interest, which is likely to be received in uneven amounts. Pechman, $A$ Practical Averaging Proposal, 7 NAT'L TAX J. 26I (1954).
} 
(4) Cumulative Assessment. Probably the most extensive averaging plan ever offered is one which suggests that the individual's income be averaged over his entire taxpaying lifetime. ${ }^{4}$ Under this plan, past income tax payments would be treated as deposits in an interest-bearing account, to be credited against the tax liability as finally computed. Running accounts would be kept of the amount of accumulated income and the amount of tax on deposit.

Income averaging plans having one or more of the characteristics outlined above have been tried in Great Britain, Australia, the state of Wisconsin, and Canada. ${ }^{\overline{5}}$ Only the Canadian plan has survived, and it is not a general income-averaging scheme because it applies only to farmers and fishermen. ${ }^{6}$

Many reasons have been advanced for the failure of incomeaveraging schemes. For one thing, many of the old plans were mandatory and were a tremendous additional burden in years when income declined. For example, the state of Wisconsin in 1927 instituted a moving-average plan based upon a three-year period. This plan was quite satisfactory during the prosperous years of the predepression boom, but it was disatrous after the crash when incomes all over the country were declining. Thus, if a taxpayer in the state of Wisconsin received taxable income of $\$ 4,000.00$ in $1928, \$ 6,000.00$ in 1929 , and only $\$ 2,000.00$ in 1930 , the taxable base for 1930 would have been $\$ 4,000.00$, or $\$ 2,000.00$ more than the actual income. Furthermore, under a mandatory system, the taxpayer is much more likely to be without funds to pay the additional tax in the year that income declines. Because of the hardship caused by this postponement of tax until the low income depression years, the state of Wisconsin abandoned its averaging plan in $1931 .^{7}$

Another objection to mandatory averaging schemes proposed in the past was that they applied to taxpayers who derived no substantial benefit from averaging. The original averaging plan adopted by Great Britain required all taxpayers to make the computations under the

\footnotetext{
- Vickrey, Agenda for Progressive Taxation 164-95 (1947); Federal Tax Policy for Economic Growth and Stability, supra note $\mathrm{x}$, at $87 \mathrm{x}$.

${ }^{5}$ Great Britain, Australia, and Wisconsin attempted varying forms of general movingaverage systems. Canada, less ambitious, introduced a limited simple averaging plan in 1949. Apparently, the Canadian plan has worked quite well and might be extended successfully to all Canadians with widely Aluctuating incomes.

${ }^{\circ}$ Can. Rev. Stat. ch. 148, \& 42 (1) (1952).

${ }^{\top}$ Driscoll, stupra note $\mathrm{I}$, at 181 .
} 
three-year averaging system, and yet, the averaging plan itself was of substantial benefit only to those taxpayers with substantial fluctuations in income. The tax relief afforded to the individual taxpayers who deserved it was outweighed by the additional paper work required of the thousands of other taxpayers who could derive no benefit from the averaging plan itself.

A third objection to averaging proposals has been that they discriminate in favor of particular groups and taxpayers. For example, as noted above, the Canadian plan applies only to farmers and fishermen. Yet, there are undoubtedly many other taxpayers in Canada who also receive income in fluctuating amounts and who are entitled to equivalent relief.

Probably all of these shortcomings contributed, to some extent, to the failure of income-averaging plans. Nevertheless, it seems that previous averaging devices had an even more basic weakness. They were simply too complicated for taxpayers to understand and too difficult for tax officials to administer efficiently. Since most other general incomeaveraging proposals have died from this chronic condition, perhaps it is useless to conceive another. However, the proposal which will be discussed at length below seems strong enough to have a fair chance of survival.

\section{III}

\section{A Workable Income-Averaging Proposal}

Congress itself has not been unaware of the need for averaging provisions in the Internal Revenue Code. Consequently, a number of specialized provisions with respect to fluctuating income have crept into the law. One of these provisions is the section which permits a threeyear carry-back and a five-year carry-forward of operating business losses. ${ }^{8}$ Without such a provision, the taxpayer who suffers a business loss in one taxable year would nevertheless be required to pay the full income tax on any income earned in a prior or subsequent year. The loss carry-over section is legislative recognition of the necessity for permitting taxpayers to deduct losses incurred in one taxable year from income earned in other taxable years. Loss carry-backs and carry-forwards, however, are not based on true averaging principles, because present law requires that the loss reduce the entire income of one year before it can be applied to another year. Although Congress might achieve

\footnotetext{
INT. REv. CODE OF 1954, § 172 (b).
} 
greater equity by permitting averaging of losses, a discussion of such improvements is beyond the scope of this article.

Of greater importance to the discussion here are the provisions in the Internal Revenue Code which permit averaging where certain types of income received in one year are attributable to several years. Section I30I of the 1954 Code provides generally that compensation from an "employment" which covers a period of thirty-six months or more may, for tax purposes, be spread back over the period of the employment which precedes the date of receipt or accrual of the compensation. Other provisions afford similar tax relief to taxpayers who receive or accrue income from inventions or artistic works, income from back pay, damages from patent infringement and breach of contract, and certain lump-sum payments received under annuity, endowment, or life insurance contracts. ${ }^{9}$ Although these provisions afford some relief, they are limited in scope, and many taxpayers who receive irregular amounts of income are unable to meet the statutory qualifications. For example, by hard work and a fortuitous combination of circumstances, a taxpayer may double his income from one year to the next. Yet, unless the increased income is received from work on a particular project, or from an invention or artistic work, or for some other source which fits into one of the listed statutory pigeonholes, the taxpayer will be unable to average his income over any number of years. As a result, the existing averaging provisions of the Internal Revenue Code, although helpful to some taxpayers, represent an additional measure of discrimination against many taxpayers who receive irregular incomes.

What is needed is not an extension of existing specialized provisions, but some sort of general over-all averaging scheme which would apply on a nondiscriminatory basis to all taxpayers with fluctuating incomes. If such a provision could be enacted, many of the present provisions which permit income averaging on an ad hoc basis could probably be eliminated. The income tax structure could thereby be simplified, and greater equity could be achieved. Of course, there must be reasonable limitations placed on even such a general averaging plan. Taxpayers who experience only minor income fluctuations from year to year do not suffer any great amount of hardship and can fairly be eliminated from consideration. Otherwise, the practical difficulties involved in administering an averaging provision of unlimited application would far

\footnotetext{
- See Taylor, Tax Relief for Income Attributable to Several Years, 36 Taxes yox (1958).
} 
outweigh the commendable objective of achieving greater fairness among taxpayers similarly situated.

Any averaging plan, however, must meet the tests of simplicity and administrative feasibility before Congress and the Treasury will seriously consider it. The present federal individual income tax return, form ro40, is sufficiently complicated as it is. Millions of taxpayers experience yearly difficulty with it, even though most of these who use the long form have no more to do than report wages subject to withholding, subtract deductions, and claim exemptions. Moreover, as the number of individual taxpayers filing returns increases, the overworked and understaffed Internal Revenue Service must process more returns, conduct more field audits, and attempt to bring a greater measure of order into an inherently chaotic situation. Any proposed change which would mean additional man-hours spent in policing returns is sure to elicit little enthusiasm in the office of the Commissioner of Internal Revenue. The proposal to be developed below, however, is based upon sections of the Internal Revenue Code which have been tested successfully in the administrative laboratory. Furthermore, this proposal is simple, workable, and would require the addition of only three or four lines to the present form I040. As subsequent discussion will show, there are no serious objections to the proposal on any ground.

A proposed new section 1348 , Internal Revenue Code of 1954 , $^{10}$ would permit income averaging at the election of the taxpayer. No taxpayer will be required to average his income; indeed, this section will not apply if income averaging results in additional tax. Thus, there is no possibility that a taxpayer would incur a greater tax liability in a year of declining income as a result of the averaging provision.

The proposed section would grant tax relief only to a taxpayer whose income in the taxable year increased by a certain percentage over the taxable income of the preceding year. The obvious purpose of the limitation is to restrict the applicability of the general-averaging plan. As previously noted, income-averaging schemes are self-defeating unless they are limited to taxpayers who have relatively severe fluctuations in income from year to year. A limitation of this type achieves two objectives: ( $I$ ) It grants relief where it is most needed on a nondiscriminatory basis, and (2) it reduces the amount of administrative work re-

${ }^{10} \mathrm{~A}$ bill containing the proposed section was submitted by the author to Rep. Curtis (R. Mo.), of the House Ways and Means Committee during the second session of the 85 th Congress. Rep. Curtis introduced the bill on August 20, 1958. 
quired to put the provision into effect. The selection of a percentage for this provision is based on the knowledge that this proposal is an experiment and that time will be needed to determine whether the section is simple enough to be understood by taxpayers and administratively enforceable by the Internal Revenue Service. It is suggested that an initial percentage of fifty per cent be used. Thus, when a taxpayer's taxable income increases more than fifty per cent over the preceding year's taxable income, he will automatically become entitled to compute his income under section 1348 . Experience will tell whether the percentage increase is too large or too small. If substantial numbers of taxpayers are able to qualify and administrative efficiency is impaired, the qualifying percentage can be raised to, for example, roo per cent and the number of taxpayers entitled to use the provision will be immediately reduced. On the other hand, if the plan proves administratively sound and brings a greater measure of compliance with the income tax laws, the required percentage can be lowered so as to entitle additional taxpayers to relief.

\section{A. Tax Computation Under Section 1348}

Once the percentage increase requirement has been met, the taxpayer may elect to compute his tax as if he had received the taxable income ratably over the taxable year and the preceding year. This means that the increase in taxable income from the preceding year to the current taxable year will be divided in half with one-half of the increase allocated to the preceding taxable year and the other half allocated to the current taxable year. The total tax burden of the taxpayer computing his tax under section 1348 will then be the same as if he had received equal amounts of income in the preceding taxable year and in the current taxable year. For example, if $A$ has taxable income of $\$ 8,000$ in the taxable year and had $\$ 4,000$ of taxable income in the preceding taxable year, under proposed new section I348, he will allocate the increase $(\$ 4,000)$ equally between both years. As a result, he will pay the same total income tax for the two-year period as he would have paid if he had received $\$ 6,000$ taxable income in each of the years.

Initially, two years including the taxable year is a sufficient number of years over which to permit allocation of the increase in taxable income. There is no necessity for using a time period in terms of months -as section 130I now provides-because there is no question of deter- 
mining when a particular project or employment giving rise to income began. If the taxpayer qualifies for section 1348 treatment by meeting the required percentage of income increase, he will be automatically entitled to spread back the increase over the statutory period. Of course, a spread-back which involves only two years will not bring substantial relief to some taxpayers who may have extreme jumps in income from one year to the next. For them, a five-year spread-back period, or perhaps even longer, is desirable. But the number of years selected need not be permanent. If experience shows that the two-year period is inadequate, it can always be lengthened.

The cornputation of income tax liability under proposed new section $\mathrm{r} 348$ will be familiar to taxpayers who have taken advantage of existing sections 1301, 1302, and 1303. These sections permit taxpayers to compute tax liability on compensation from an employment, on income from an invention or artistic work, and on back pay as if such income had been received in equal installments over prior years. The income is still reported in the year of receipt or accrual, and the tax on all of the income is still assessed for the current year; only the computation of the amount of tax liability involves prior years.

Similarly, under the proposed new section, the taxpayer concerned will report all of his taxable income and pay all of his tax liability for the taxable year, but he will compute the tax as if he had received a part of the income ratably over the taxable year and preceding year. In making this computation, the taxpayer must add the income allocable to the preceding year to the income already reported for that prior year and pay tax on the spread-back portion at the rate applicable to the preceding year. For example, if taxpayer $A$ is permitted to spread taxable income of $\$ 10,000$ ratably over 1957 and 1958 , he will add $\$ 5,000$ to his taxable income for 1957 and pay income tax on the $\$ 5,000$ at the 1957 rate applicable to the total of the spread-back portion plus the taxable income already reported for that year. Thus, if $A$ had received $\$ 5,000$ of taxable income in 1957 , the addition of the $\$ 5,000$ spread-back income would result in a 1957 tax rate applicable to $\$ 10,000$ of taxable income. A detailed illustration will more effectively show the mechanics of the computation:

Assume that taxpayer $A$ received $\$ 5,000$ taxable income in 1957 and $\$$ I 5 ,000 taxable income in 1958 . 
Tax Liability Computation for 1957 and 1958 under Present Law Year Taxable Income Tax Liability

$1957 \$ 5,000$

Total $\quad \frac{15,000}{\$ 20,000}$ $\$ 1,100$ $\frac{4,730}{\$ 5,830}$

Tax Liability Computation under Proposed New Section I348 Year Taxable Income Tax Liability

I957 $\$ 5,000$ 5,000 (from I957) $\$ 1,100$ $\frac{5,000}{\$ 10,000}$ (increase allocated to I957)

Less Tax Paid in 1957 $\mathrm{I}, \mathrm{I} 0 \mathrm{O}$

1958

Tax on $\$ 5,000$ increase allocated to $1957 \$ 1,540$

$\$ 5,000$ (increase allocated to 1958 ) 5,000 (for 1958)

Total

$\$ \mathrm{Y0,000}$ Tax on this amount

2,640

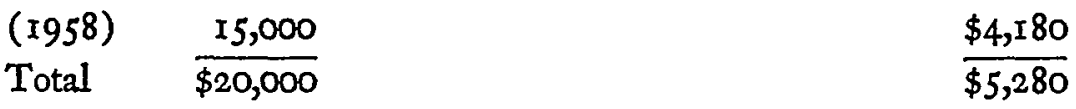

Under proposed new section 1348 , taxpayer $A$ will have a tax saving of $\$ 550$. Also, by using the new section, he will pay the same tax he would have paid if he had received $\$ 10,000$ of taxable income in each of the years $\times 957$ and 1958 .

In making the computation under section 1348 , taxpayer $A$ would also adjust items contained in the 1957 income tax return which depend upon the amount of gross income, adjusted gross income, or taxable income. " For example, the standard deduction, the limitation on allowable charitable contributions, and the limitation on medical expenses for the year 1957 would be affected by the allocation of income from 1958 . Such adjustments would be computed in the same manner that adjustments in prior years are now made under existing section $1301 .{ }^{11}$

B. Evaluation of Proposed New Section 1348

The relief proposed in new section 1348 will be simple to explain on form I040 and easy to administer. The only changes required can

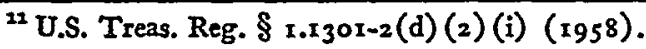


be made on page two of form I040 under the heading "Tax Computation." Line five under the heading is entitled "Taxable Income." After line five, the following lines can be inserted:

5a. Taxable income of preceding year

(line 5 of preceding year's return)

5 b. Excess of line 5 over line $5 \mathrm{a}$

5c: If amount on line $5 \mathrm{~b}$ is $50 \%$ or more of amount on line $5 \mathrm{a}$, compute tax on amount on line $5 \mathrm{~b}$ as if this amount had been received one-half in taxable year and one-half in preceding year

6. Tax on amount on line 5 (less amount on line $5 \mathrm{~b}$ if line $5 \mathrm{c}$ is used)

Total Tax

New section 1348 can thus be incorporated into form 1040 in less space than was required to provide for the retirement income provisions. An explanatory note in the information pamphlet and a simple illustration should be sufficient to explain the steps involved in computing income tax liability under the proposed new section.

There will be little additional auditing involved of those returns which take advantage of the section 1348 computation. The face of the return will disclose the taxable income of the current taxable year, the taxable income of the preceding year, and the percentage of increase. If any audit is necessary, it will be a simple matter to check the return for the prior year and compare the taxable income in that return with the taxable income disclosed on the face of the return for the current year. Since Internal Revenue Service personnel are accustomed to dealing with computations under existing sections I301, 1302 , and ' 1303 , they will have no difficulty in checking computations under the proposed new section. Prior difficulties with section I3OI have stemmed from determinations by the Commissioner that compensation was not received from "a particular project" or that not more than eighty per cent of it was received in one taxable year. ${ }^{12}$ The use of new section 1348 will not involve any of these administrative questions. The only condition precedent to the use of the section will be the required percentage of taxable income increase.

Proposed new section 1348 will have no effect on the withholding

\footnotetext{
${ }^{12}$ Taylor, supra note 9, at 703 .
} 
provisions. Taxpayers receiving wages and salaries will follow the same procedures for reporting income taxes withheld. The only difference will be that if they qualify under new section 1348 , their computation of tax liability under that section may entitle them to refunds. Nor will the proposal hamper payments of estimated tax. Again, taxpayers will follow familiar procedure, but if at the end of the year they qualify under new section 1348 , they will be entitled to recompute their tax liability and claim any refunds due.

New section 1348 has an additional advantage in that it is not based in any way on source of income. For example, an individual who receives the proceeds of an endowment policy is now allowed under section 72 (e)(3) of the I954 Internal Revenue Code to pay a tax computed as if the income had been received over a three-year period. Such a provision unfairly discriminates against other taxpayers similarly situated. Holders of United States savings bonds may receive ten or twenty years of interest in the one year in which the bond is cashed. Should they not be entitled to spread back the interest income they received if the recipient of endowment proceeds is so favored? Accumulated dividends on preferred stocks are also lumpy in character, and large amounts are likely to be received in one year. Are the recipients of such dividends also not entitled to similar averaging relief? Obvious$\mathrm{ly}$, to base income averaging relief ' on type of income received-no matter how irregularly the income is likely to arrive in the hands of the taxpayer-is a certain way to create unfairness and discrimination among taxpayers. As a result, disgruntled taxpayers may bring pressure to have their types of income qualified for averaging relief. The proposal to use new section 1348 on the basis of percentage of taxable income increase is free from any such infirmity and will extend relief to any taxpayer who qualifies by reason of a substantial jump in income, regardless of the source of that income.

It can be argued that new section 1348 is deficient because it contains no provision for taxpayers who may have many lean years and then many fat ones in succession. This is quite true, for a taxpayer whose income jumped from $\$ 5,000$ to $\$ 15,000$ in one year and then remained at the latter level for several years, would receive the benefit of new section I348 in only one taxable year. However, the suggested plan does not propose to provide adequate relief for taxpayers who may enjoy several years of stable prosperity after several years of poverty. Those taxpayers who reach an income peak which lasts for only a few years would 
benefit more from some form of deferred compensation arrangement whereby they could postpone the collection of some of their income in peak years to later years when earning power seriously declined. ${ }^{13}$ Professional athletes are a classic example of this group of taxpayers, for their peak earning periods are often less than ten years. Although the plight of these taxpayers induces sympathy, the temptation to propose too much must be resisted. The purpose of proposed new section I348 is to grant relief only to those taxpayers who pay substantially higher taxes because of income increases from year to year.

Even in this limited form, however, many taxpayers who enjoy only short periods of high earnings would find that their incomes fluctuated sufficiently to entitle them to the benefit of the proposed section on many occasions. For example, a baseball player who entered the major leagues at an $\$ 8,000$ salary; made the grade and jumped to $\$ 13,000$ the next year; had a good season which justified a rise in income to $\$ 22,000$; and then became a star at $\$ 35,000$; would be entitled to spread back his income under the proposed new section in each year of increase.

The proposed new section makes no provision for declining incomes. However, the taxpayer with declining income is paying a substantially smaller amount of tax as his income declines. Just as the progressive rates operate to take more of his taxable dollar as he goes up the scale, so does the system benefit him by taking less as he goes down. Furthermore, whenever he recovers and increases his income substantially, he may qualify for section 1348 relief and save some of his increased income. Greater equity would probably be accomplished if some overall averaging scheme could be devised which provided for income averaging on the downswing as well as on the upswing. But any such plan would be complicated and sure to cause serious questions of administrability.

Loss of revenue is not a serious objection to the proposed new section. Even under the more extensive averaging systems which range over many years and which include such features as progressive averages, carry-overs of unused exemptions, and the like, experts have estimated that less than two million taxpayers would be affected. ${ }^{14} \mathrm{Be}-$ cause the percentage of increase in taxable income to qualify under pro-

${ }^{13}$ The Jenkins-Keough bill, H.R. ro, $85^{\text {th }}$ Cong. 2d Sess. (1958), which would permit a deduction for retirement deposits by self-employed individuals, is an example of such relief.

"Steger, supra note $\mathrm{I}$, at rog. 
posed section $\times 348$ will be at least fifty per cent (or even higher if necessary), it is submitted that far fewer than two million taxpayers will be entitled to its benefits. Of these, none will save large amounts of taxable income in view of the restriction of spread-back to two years. Certainly, some revenue will be lost, but because of the limited applicability of new section $\mathrm{r} 348$, that loss will be inconsequential.

The observation that the majority of taxpayers would be unaffected by new section 1348 also disposes of the argument that averaging proposals run counter to and have an adverse effect on the economic flexibility of the progressive income tax system. ${ }^{15}$ The argument is that in a period of rising incomes, the progressive rates will drain off much of the increase and reduce inflationary pressures, but that if taxpayers are permitted to average incomes, this countercyclical effect of the progressive rate structure will be blunted. This argument might have some validity if millions of taxpayers experiencing minor income fluctuations were permitted to spread back their incomes. Because of the restricted nature of new section 1348 , however, the few taxpayers who qualify will not receive tax benefits of sufficient magnitude to have any appreciable effect on the flexibility of the progressive income tax system.

\section{Conclusion}

Although the proposal to create a limited form of general income averaging under proposed new section 1348 will apply to relatively few taxpayers, these few are justly entitled to relief. For years, they have borne more than their fair share of the tax burden because they have occupations which produce incomes in irregular quantities. Relief which is fair and which is long overdue should never be denied because the beneficiaries will be few in number.

Dynamic growth in the economy is frequently due to individual ambition and personal effort. These efforts often result in financial success which is a boon both to the individual who achieves it and to the nation. The tax system should offer some incentive to the taxpayer who is willing to work toward higher income; who is willing to risk his time, his brains and his inoney for ultimate reward. Yet, despite the claims

\footnotetext{
${ }^{15}$ There is disagreement as to whether the tax structure should be used to accomplish deliberate economic changes. Compare Bastable, Public Finance (3d ed. 1903), with Dalton, Princtpless of Public Finance (1946). However, Congress has followed generally the view that progressive income taxes are a desirable means of reducing the sevirity of economic cycles. See Federal Tax Policy for Economic Growth and Stability, supra note 1 .
} 
of many economists to the contrary, ${ }^{16}$ our progressive income tax rates do have a depressing effect on some incentives-certainly on the incentive to earn more taxable income. Because of the requirements of national defense and a growing federal budget, however, those progressive rates will probably remain high. The averaging scheme proposed in these paragraphs should restore some of the incentive which may have been lost by capable and industrious individuals. The plan permits them not unlimited tax privileges, but some relief when their success results in a substantial increase in income. The plan is simple and puts no burden on the Government either in terms of substantial loss of revenue or in loss of manpower hours to enforce it. New section $\mathrm{r} 348$; in sum, offers an opportunity to afford workable tax relief where it is needed and where it is justifiable.

${ }^{10}$ E.g., Heller, Limitations of the Federal Individual Income Tax, 7 J. Finance 185 (1952). 